\title{
(16) 高分子科学最近の進歩
}

\section{フラーレン化学最近の進歩}

\author{
山子 茂 Shigeru YAMAGO, 京都大学工学部 \\ 中村 栄一 Eiichi NAKAMURA, 東京大学大学院理学 \\ 系研究科
}

1. はじめに

フラーレンは閉じた 3 次元的な中空構造が歪んだ $\mathrm{sp}^{2}$ 炭素同士の共有結合によって作りだされている，これま でにない新しい構造をすう炭素同素体である．他の炭素 同素体であるダイヤモンドやグラファイトと異なり，分 子性をむつ点であ際だった特徴をむつ化合物群である. 1990 年の Kratschmer, Huffman によるフラーレンの 大量合成法の発見以来，この全く新しい化合物は，多く の科学者，技術者の興味を引き，その分子の性質，その 集合体の物性，さらにはその炭素材料としての利用等の 幅広い視点から多くの研究が多方面で同時進行してい る1!.なかでも, フラーレン誘導体が光導電性ポリマーや 触媒, さらには医薬・診断薬になる可能性が示唆されて 以来, フラーレン骨格の外部 (エキソヘドラル) に他の 化合物を結合させることにより両者の特徵を合わせ持つ ハイブリ，ド分子群を作る試みが盛んに行われるように なってきている2!.ここでは, フラーレンのエキソヘドラ ルな化学の最近の進歩について, フラーレン誘導体の合 成法とその応用的利用について紹介する.

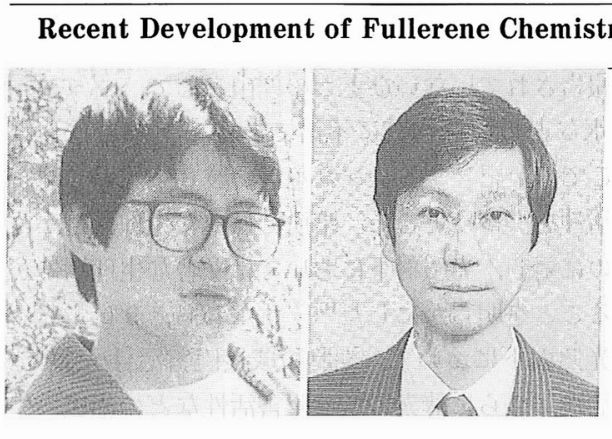

高分子 44 巻 7 月号 (1995 年)

\section{2. フラーレンの化学反応性}

フラーレンは骨格歪みをむつ $\mathrm{sp}^{2}$ 炭素より成り，その $\pi$ 結合はフラーレン骨格の外側に張り出している. さら に，当初考えられていたような芳香族化合物というより 屯共役ポリオレフィンとしての性質を示し, 低いイオン 化ポテンシャルと共に高い電子親和力をもつ. 換言すれ ば, HOMO-LUMO ギャップが小さいことから高い反応 性を示す. フラーレンの最も代表的な化合物である $\mathrm{C}_{60}$ に対しては，さまざまな反応が試されており，求核反応 剤, 求電子反応剤共に $\mathrm{C}_{60}$ に対して高い反応性を示すこ とが明らかとなっている， $C_{60}$ は還元電位が低い $(-0.36 \mathrm{~V}$ vs SCE, ベンゼン溶液) と共に, 最高 6 個の 電子を受け取ってへキサアニオンにまで還元されること から，フラーレンを電子受容体として用いる反応はこの 化合物の最も一般的な反応となっている゙!. すなわち, $\mathrm{C}_{60}$ 上の二重結合は電子不足性を示すため, これに対し これまでにカルベン, エノールエーテル4), ジアゾメタン やアゾメチンイリドさらにトリメチレンメタン等の 1,3-双極子, ジェンが室温程度の穏和な条件で反応し, それぞれ 3 6 員環構造をむつ化合物が得られることが 明らかになっている．また，有機リチウム試薬やグリこ ヤール試薬，あるいはエノラート等占の求核性の高い有 機典型金属化合物も $\mathrm{C}_{60}$ に対して速やかに反応すること が明らかになっている.

一方，ケテンシリルアセタールやイナミンのような求 核性の弱い反応剤はこのままでは反応しない。しかし， 反応溶液に光を当ててフラーレンを活性化することによ り反応が速やかに進行することがわかってきだ). すな わち, $\mathrm{C}_{60}$ の溶液が紫色をしていることから推察される ように, フラーレン類は紫外から可視領域にかけての光 を吸収する. 光励起された $\mathrm{C}_{60}$ の還元電位は約 $1.14 \mathrm{~V}$ vs SCE であり, $\mathrm{C}_{60}$ そのあのより還元されやすくなって いる7). すなわち高い求電子性を示すことから, 弱い求核

山子 茂 京都大学工学部大学院合成・生物化学専攻 (606-01 京都市左京 区吉田本町) 助手, 理博 (写真左)

1986 年東工大理学部化学科卒, 1991 年東工大大学院理工学専攻科修了. 同年東工大理学部化学科助手, 1995 年より京大工学部助手. 専門は有機化 学.〈趣味〉運動, 旅

中村栄一 東京大学大学院理学系研究科 (113 東京都文京区本郷 7-3-1) 教授, 理博 (写真右)

1973 年東工大理学部卒. 1993 年東工大教授, 1995 年東大大学院理学系研 究科教授. 専門は有機化学. 〈趣味〉音楽, 山歩き 

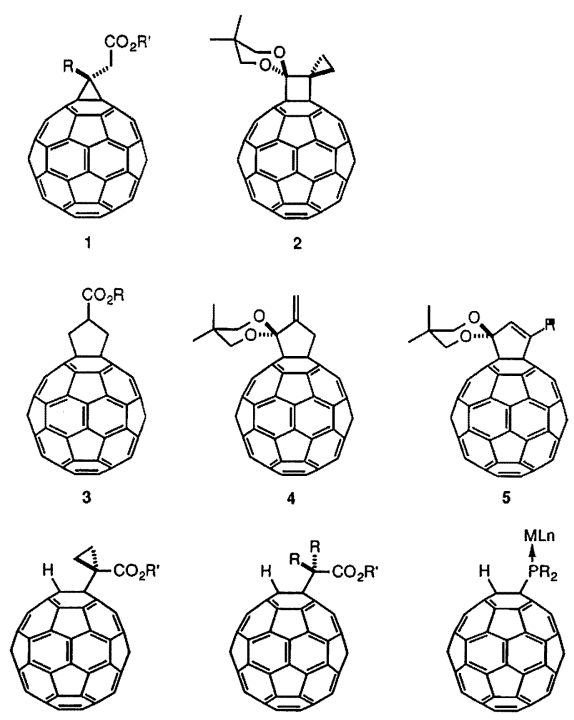

6
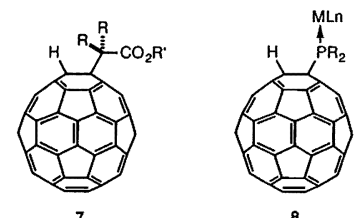

図 1 有機フラーレン誘導体の構造

反応剤であ十分に反応できるようになるのである．

図 1 にわれわれの研究室で開発した手法を用いて合 成した $\mathrm{C}_{60}$ 誘導体の骨格の基本構造を示す， $\mathrm{C}_{60}$ は土キ ソヘドラルの結合生成に関して，6員環と 6 員環の間 (6,6-位) と 5 員環と 6 員環の間 (5,6-位) で結合を形成 する二つの形式をむつ. しかし，われわれの得た生成物 はいずれも6,6-位に置換基をむつ生成物であった．

これらの検討により, 電子受容体としてフラーレン類 の反応性が明らかになったと共に，フラーレンにさまざ まな有機官能基を導入することも可能になった．これら の生成物の可視-紫外吸収スペクトルや還元電位等のフ ラーレンに特長的な物性は $\mathrm{C}_{60}$ 自体と比べほとんど変化 しない一方, 導入した有機官能基の影響により, フラー レン化合物を取り扱う上で一般的に問題となる溶解性や 分離精製の困難さを大きく改善できることがわかった.

\section{3. フラーレンハイブリッドの合成}

上記反応で得られた生成物の最大の特長は, アルコー ル基などの反応性の高い官能基をもつ点である，あし有 機官能基の特長的反応性を活汃し, 反応性の高い $\mathrm{C}_{60}$ 部 位を損なうことなく選択的に官能基での化学变換が行え れば，これもまた新しい有機フラーレン類の合成法とな ると考えられる，実際， $\mathrm{C}_{60}$ 部位は強い塩基性条件に対 しては活性であり不安定であるが, 弱い塩基性から強い 酸性条件下, さらに酸化条件に対しては安定であり, 種々の選択的官能基変換反応が可能であることが明らか になった。これらの検討により, アルコール部位のエス

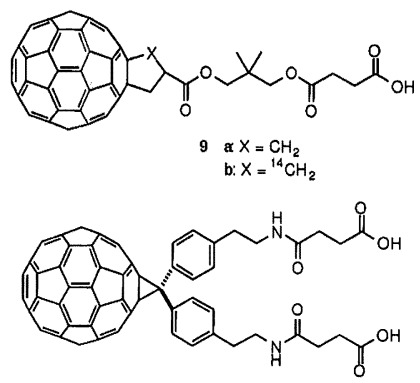

10

図 2 水溶液に可溶なフラーレンカルボン酸の構造

テル化やエーテル結合生成反応によりアミノ酸や糖を分 子内にもつフラーレン誘導体が合成できだ). フラーレ ンは非極性化合物であり，水などの極性溶媒に対しては 全く不溶である。しかし，上記手法を用いて合成した， カルボン酸残基をあつフラーレン誘導体 9 は水に可溶 であると共に, 以下に述べるように, 生理活性 ${ }^{91}$ や有機材 料化学の分野 ${ }^{10)}$ で, 非常に興味深い性質をむつことが明 らかになった。 また，われわれとほぼ同時に，ジアゾメ タンと $\mathrm{C}_{60}$ との反応生成物での選択的化学変換により得 られた 3 員環構造をむつフラーレンジカルボン酸 10 あ, 水に可溶であると共に興味深い生理活性を示すこと がわかった11).(図2)

\section{4. フラーレン誘導体の生理活性}

フラーレンを研究する上で一つの問題点はこれらの化 合物の生体（研究者を含む）への影響である. 特に, ピ レンを代表とするポリ芳香族化合物が発癌性物質として よく知られていることからも, フラーレン誘導体の毒性 の検討は必須の課題である. 他方, フラーレンの反応性 や活性酸素発生能, さらにその特徽的な構造を考える と, 適当な置換基をむつフラーレン誘導体がフラーレン を活性部位とする医薬や診断薬に用いられる可能性むあ り, フラーレンの生理活性は興味深い分野である.

高い化学反応性や光化学的性質からフラーレンが生理 活性をむつ可能性が指摘されていたが, 1992 年に至る までその直接的な証拠はなかった ${ }^{12)}$. フラーレンの生理 活性が報告されていないひとつの理由として, フラーレ ン類が水などの極性物質に不溶であることがあげられ る. そこで, 上記フラーレンカルボン酸 9 を用いて種々 の生理活性を調べたところ, 暗所では全く生理活性がな かったのに対し, 光照射下においては顕著な生理活性が 発現することを明らかにした ${ }^{10)}$. すなわち，9 は蛍光燈 程度の光照射下に扔いて, 細胞の成長阻害活性や DNA の切断活性, さらに酵素の活性阻害活性などの幅広い生 
理活性を示した。ささまざまな対照実験により,・生理活性 の発現にはフラーレン誘導体の水に対する溶解性と, 光 励起されたフラーレン誘導体の一重項酸素生成能力とが 関与していることが示唆された.この結果は, フラーレ ン誘導体がガンの光力学的療法に用いられる可能性を示 唆している. この点に関しては, 長波長の赤外部位の光 を効率良く吸収することが望ましく， $\mathrm{C}_{60}$ よりも高次〉 ラーレンの方が相応しいと考えられる. 現在活発に検討 が行われている高次フラーレンの官能基化の検討によ り, フラーレン誘導体が光力学的療法に用いられる日が 来ることが期待される.

さらに，最近，DNA の塩基配列を選択的に認識する 有機残基を $\mathrm{C}_{60}$ と連結させることにより，二重鎖 DNA の塩基配列を高度に選択して切断できることがわかっ た ${ }^{13)}$. すなわち，標的 DNA に対し Watson-Crick およ び Hoogsteen 型の水素結合を形成する相補的な塩基配 列をむつ核酸 (14 量体) をフラーレン誘導体 1 と結合し て11を合成した（式 1)。これを，一重鎖，二重鎖，お よびヘアピン構造をもつ二重鎖 DNA に作用させて光を 照射したところ，フラーレンの近傍にあるグアニン塩基 で選択的に DNA 鎖の切断が起こることがわかった.

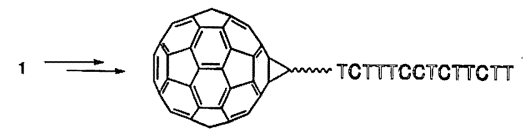

11

フラーレン核酸ハイブリッドとDNA との相互作用の 模式図を示す（図 3). $\mathrm{C}_{60}$ は大きな分子量にもかかわら ずコンパクトな構造をしているため， $\mathrm{C}_{60}$ 部位は DNA の大きな溝にうまく入り込める可能性があることがわか る.このような選択的 DNA 鎖の認識抢よび切断は, 将 来のゲノムの塩基配列決定法や遺伝子治療薬としての利 用の可能性を期待させる ${ }^{144}$.

米国のグループは, 水溶性フラーレン誘導体 10 が抗

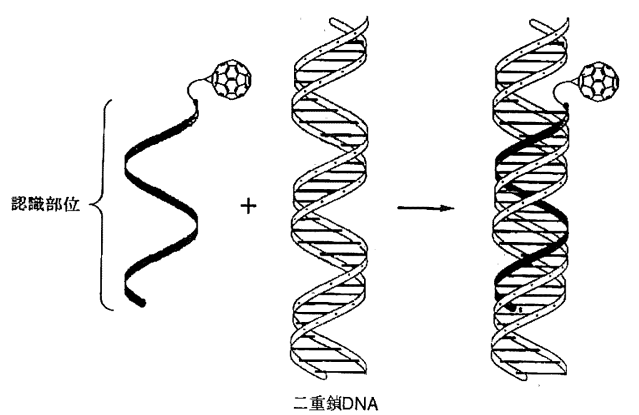

図 3 フラーレン誘導体による DNA 二重鎖の選択 的認識
AIDS ウイルス活性および HIV protease 阻害活性を示 すことを明らかにしている11.15).ここでは, フラーレン は HIV 蛋白質分解酵素の活性部位ポケットにちょうよ゙ はまり込む形になっていて，フラーレンと酵素の活性部 位との疎水性相互作用が重要であることが示唆されてい る.

以上の結果から，フラーレンの in vitro の活性に関す る興味が持たれているが，この点に関する最む基礎的な 情報である体内への取り込み, 分布, および排泄といっ たフラーレンの動態，そして急性毒性に関する情報は全 くなかった，そのような研究に必須の放射線同位体標識 をしたフラーレン誘導体 9b の合成を行い，ラットにお ける系口投与, 静脈投与における体内動態の検討を行っ た ${ }^{16)}$. その結果, 水溶性フラーレンカルボン酸の ADL は>500 $\mathrm{mg} / \mathrm{kg}$ (腹腔内投与) であり急性毒性はないと の結論を得た。 また，9bの経口吸収はほとんどないこと からあ, フラーレン誘導体を取り扱う上で急性毒性の問 題ないことが示唆された。 しかし, 静脈投与.場合は 1 週間後にもほとんど体内から排泄されず, 肝臟や腎臟な どの種々の臟器を経て, 最終的に骨格筋や脂肪などの組 織に蓄積されることから，フラーレン誘導体の長期的な 生体に及ぼす影響に関してはさらに検討が必要である. 以上の結果から，フラーレンは，注意して取り扱うかぎ り，十分に安全な化合物であると結論できよう.

\section{5. フラーレン誘導体の応用}

フラーレン薄膜やフラーレン含有ポリマーには, 光導 電性や導電性ポリマーや非線形光学材料, さらには触媒 などの応用が期待されている.

薄膜の作成法として LB 膜法が良く知られている。し かし，フラーレンは非極性物質であるために水に展開し ても単層膜を作るのが非常に困難であると共に, 生成し た膜む安定性が低いためにそれを他の基板上に移すこと はできなかった，そこで，適当な官能基をむつフラーレ ン誘導体を用いることにより, LB 膜生成を制御する研 究が盛んに行われてきている.

われわ机は先に示したフラーレンカルボン酸 9 が非 極性分子であるフラーレン部位と極性官能基のカルボン 酸部位をむっている典型的な両親媒性分子である点に着 目し，LB法を用いた薄膜化について検討した。この結 果, フラーレンカルボン酸を水上に展開することによ り，単分子膜を容易に形成することがわかった，すなわ ち, フラーレンカルボン酸を水面上に展開したところ, 図 4 に示す $\pi-\mathrm{A}$ 曲線が得られた. $\pi$ - $\mathrm{A}$ 曲線において直 線部分を $0 \mathrm{mN} / \mathrm{m}$ に外挿して得られる極限分子占有面 積は $0.78 \mathrm{~nm}^{2}$ であり, $\mathrm{C}_{60}$ を水面上に展開した場合より も大きく, かつ $\mathrm{C}_{60}$ の結晶構造から予想される $\mathrm{C}_{60}$ 分子 


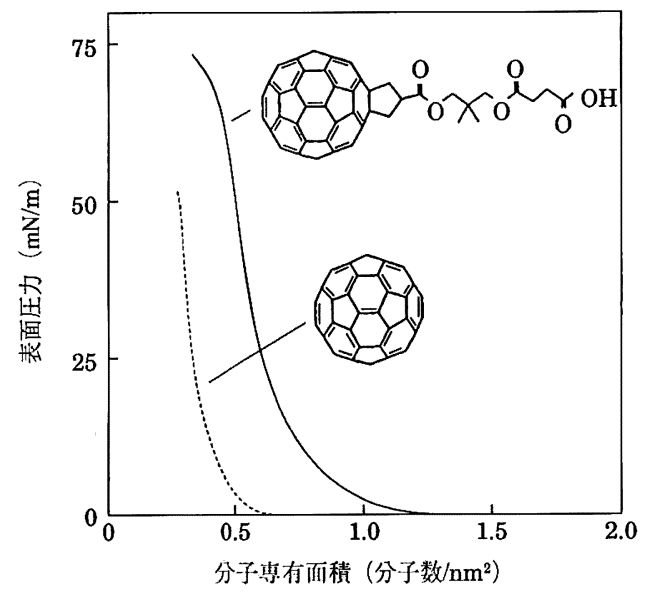

図 4 フラーレンカルボン酸の $\pi$-A 曲線

一分子当たりの占有面積 $\left(1.0 \mathrm{~nm}^{2}\right)$ に近い值を示してい ることがわかった．このことから，フラーレンカルボン 酸は水面上で単分子膜を形成していることが示唆され る. また, 崩壊圧がかなり高いことから, 安定な膜が形 成されている.さらに, 水面上に生成した膜を水平付着 法あるいは垂直浸漬法によりさまざまな基板上に累積す ることにより，X型累積膜が生成することがわかった。

もうひとつの薄膜合成法としては，適当な基板上に薄 膜を作っていく方法である. 例えば，四酸化オスミウム と $\mathrm{C}_{60}$ との反応を利用したシリコン表面での薄膜合成が あげられる17).ここでは, シリコン表面にある末端にピ リジンをむつシロキサンを基板として用いることによ り， $\mathrm{C}_{60}$ に四酸化オスミウム付加体が自己縮合した単分 子膜 12 が生成した. また, 極く最近, アゾメチンイリド の $[3+2]$ 付加環化反応を用いて合成した, 末端にチ才 ールをむつフラーレン誘導体 13 が，金の表面に自己集 合した単分子膜を生成することが明らかになった ${ }^{18)}$ 。こ れらの薄膜は, いずれもフラーレン部分が置換基部分に 比べて十分に大きいために, 膜表面にはフラーレン部位

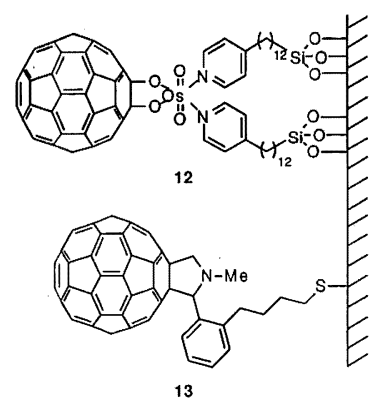

図 5 フラーレン自己集合膜の構造

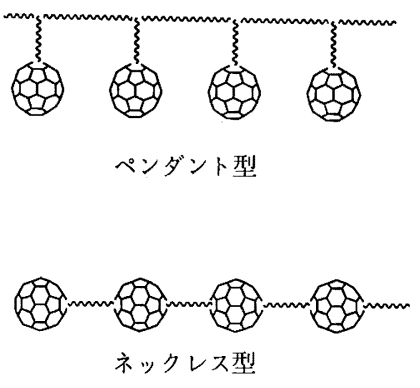

図 6 含フラーレンポリマーのプロトタイプ

だけが露出していることが予想されており, 今後これら の膜を用いた物性研究が進んでいくことが期待される.

含フラーレンポリマーのプロトタイプとしては, ペン ダント型とネックレス型の二つが考えられている（図 6). すなわち, ペンダント型ポリマーにおいては，ポリ マー主鎖からフラーレンをあつ側鎖が結合している構造 であるのに対し，ネックレス型ではフラーレンが主鎖の 構成ユーットとなっている.

ペンダント型ポリマーである含フラーレンポリエステ ル 15 およびポリアミドは, 水酸基をもつメタノフラー レン誘導体 14 とセバコイルクロリドやへキサメチレン イソシアナートとの縮合により最初に合成された（式 $2)^{19)}$. これらのポリマーにおいても, フラーレンの特徽

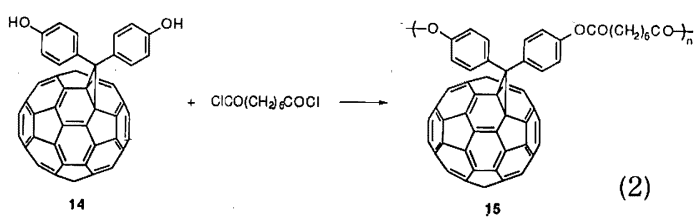

的な性質である紫外一可視光吸収や電気化学的な性質は 基本的に残されていることが示唆された，最近では，シ クロペンタジェンが側鎖にされたポリマーと $\mathrm{C}_{60}$ との Diels-Alder 反応抢よび逆反応により，可逆的に $\mathrm{C}_{60}$ を ポリマーに結合することも可能になってきた ${ }^{20)}$.

ネックレス型ポリマー合成においては, フラーレンの 多数個の二重結合に対するポリマー鎖の結合位置の選択 性および鎖の数が問題になってくるため，これまで構造 の明確なものは得られていない. 現在活発に研究されて いる位置選択的なフラーレンの多官能基化反応の開発に より ${ }^{21)}$, この問題も解決されることが期待される.

むうひとつの含フラーレン高分子として最近注目され ているあのが, フラーレンデンドリマーである ${ }^{221} . \times 夕$ /フラーレン 14 と 4 世代デンドリーマー 16 との縮合 によりデンドリーマー 17 が高収率で得られた（式 3).

17 およびその類似化合物においては，フラーレンデン 


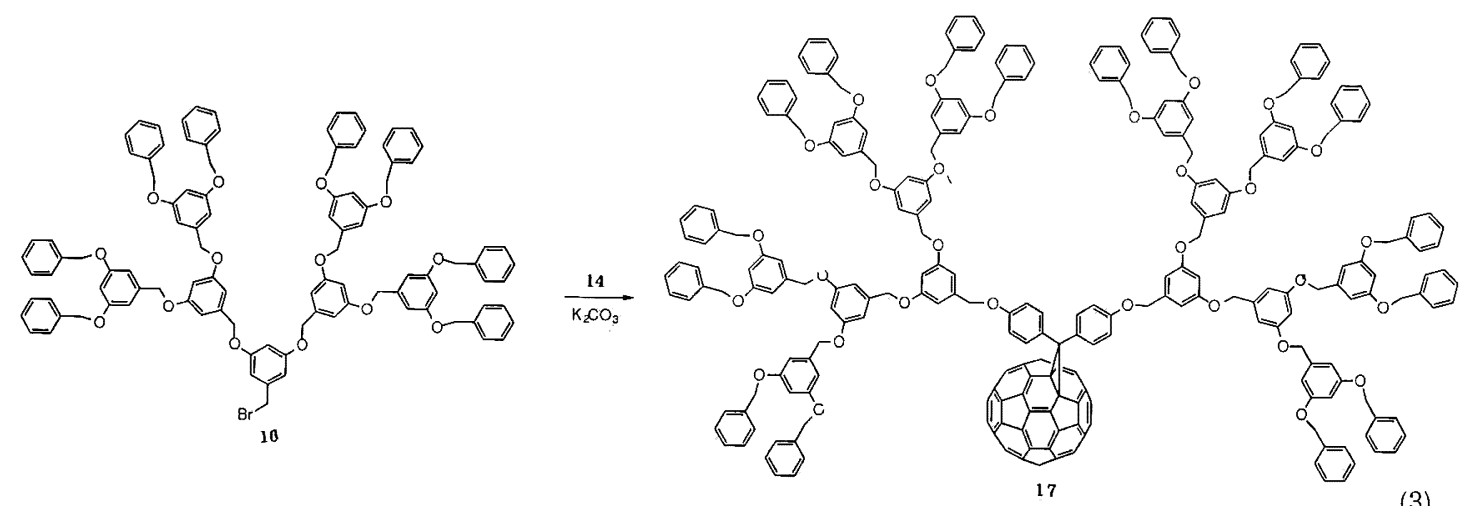

(3)

ドリーマーは溶解度が大幅に増大すると共に, フラーレ ン部位に由来する還元電位の低下，および出発デンドリ ーマーに比べガラス転移温度が上昇するなど，フラーレ ンとデンドリーマー部分との相互作用による物性の変化 が起こることが明らかになっている.

\section{6. おわりに}

エキソヘドラル化学の手法を用いフラーレンと他の機 能分子とを結び付けると，単に両者の性質を足し合わせ ただけではなく，掛け合わせたような性質をあつ新しい 分子群が得られることが明らかになってきている．これ らの新しいフラーレン群の合成とその機能探索は, 高次 フラーレンや金属内包フラーレン, さらにはカーボンナ /チューブ等の新しいフラーレン系炭素素材の探索と相 合わさり 23)，1990 年以前には誰にむ予想できなかった 新しい性質をもつ炭素分子ライブラリーを構成していく ことが期待される. また, フラーレン研究で多くの興味 を集めている超伝導, 有機磁性体, あるいは光導電性な どのマクロな物性に扔いても，フラーレン分子の性質が 大きく影響していることから，フラーレン分子自体のミ クロな性質を積極的に变化させる必要性があり，ここで もエキソヘドラルの化学が大きな寄与をすることが期待 される.

\section{文献}

1) Special Issue on Buckminsterfullerene, Acc. Chem. Res., 25[3] (1992); 「化学」編集部編： $C_{60}$ ・フラーレンの化学, 化 学同人 (1993); K. M. Kadish, R. S. Ruoff Eds: Fullerenes, The Electrochemical Society Inc. (1994)

2) A. Hirsch: The Chemistry of the Fullerenes, Georg Thieme Verlag (1994)

3) 山子 茂, 中村栄一: 化学, 48, 498 (1993)

4) S. Yamago, A. Takeichi, E. Nakamura: J. Am. Chem. Soc., 116, 1123 (1994)

5) C. Bingel: Chem. Ber., 126, 1957 (1993)

6) X. Zang, A. Romero, C. S. Foote: J. Am. Chem. Soc., 115, 11024 (1993); H. Tokuyama, H. Isobe, E. Nakamura: $J$. Chem. Soc., Chem. Commun., 2753 (1994)
7) J. W. Arbogast, C. S. Foote, M. Kao: J. Am. Chem. Soc., 114, 2277 (1992)

8) S. Yamago, H. Tokuyama, E. Nakamura, M. Prato, F. Wudl: J. Org. Chem., 58, 4798 (1993)

9) H. Tokuyama, S. Yamago, E. Nakamura, T. Shiraki, Y. Sugiura: J. Am. Chem. Soc., 115, 7918 (1993)

10) M. Matsumoto, H. Tachibana, R. Azumi, M. Tanaka, T. Nakamura, G. Yunome, M. Abe, S. Yamago, E. Nakamura: Langmuir, 11, 660 (1995)

11) S. H. Friedman, D. L. DeCamp, R. P. Sijbesma, G. Sradanov, F. Wudl, G. L. Kenyon: J. Am. Chem. Soc., 115, 6506 (1993); R. F. Schinazi, R. Sijbesma, G. Sradanov, C. L. Hill, F. Wudl: Antimicro. Agents Chemo., 37, 1707 (1993)

12) M. A. Nelson, F. E. Domann, G. T. Bowden, S. B. Hooser, Q. Fernando, D. E. Carter: Toxicol. Ind. Health, 9, 623 (1993)

13) A. S. Boutorine, H. Tokuyama, M. Takasugi, H. Isobe, E. Nakamura, C. Héléne: Angew. Chem., Int. Ed. Engl., 33, 2462 (1994)

14) J. S. Cohen, M. E. Hogan: Scientific American, 50 (1994)

15) C. Toniolo, A. Bianco, M. Maggini, G. Scorrano, M. Prato, M. Marastoni, R. Tomatis, S. Spisani, G. Palu, E. D. Blair: J. Med. Chem., 37, 4558 (1994)

16) S. Yamago, H. Tokuyama, E. Nakamura, K. Kikuchi, S. Kananishi, K. Sueki, H. Nakahara, S. Enomoto, F. Ambe: submitted for publication

17) J. A. Chupa, S. Xu, R. F. Fischetti, R. M. Strongin, J. P. McCauley, Jr., A. B. Smith, III, J. K. Blasie: J. Am. Chem. Soc., 115, 4383 (1993)

18) X. Shi, B. Caldwell, K. Chen, C. A. Mirkin: J. Am. Chem. Soc., 116, 11598 (1994)

19) S. Shi, K. C. Khemani, Q. C. Li, F. Wudl: J. Am. Chem. Soc., 116, 5997 (1994)

20) K. I. Guhar, M. D. Greaves, V. M. Rottello: J. Am. Chem. Soc., 116, 5997 (1994)

21) L. Isaacs, R. F. Haldimann, F. Diederich: Angew. Chem., Int. Ed. Engl., 33, 2339 (1994); A. Hirsch, I. Lamparth, T. Grösser, H. R. Karfunkel: J. Am. Chem. Soc., 116, 9386 (1994)

22) K. L. Wooley, C. J. Hawker, J. M. Fréchet, F. Wudl, G. Stdanov, S. Shi, C. Li, M. Kao: J. Am. Chem. Soc., 115, 9836 (1993); C. J. Hawker, K. L. Wooley, J. M. Fréchet: J. Chem. Soc., Chem. Commun., 925 (1994)

23）永瀬 茂, 小林 郁, 赤阪 健: 季刊フラーレン, 2 [5], 124 (1994) 